\title{
Associations between olfactory pathway gene methylation marks, obesity features and dietary intakes
}

Omar Ramos-Lopez ${ }^{1,2+}$, Jose I. Riezu-Boj ${ }^{1,3+}$, Fermin I. Milagro ${ }^{1,4}$, M. Angeles Zulet ${ }^{1,3,4}$, Jose L. Santos ${ }^{5}$, J. Alfredo Martinez ${ }^{1,3,46^{*}}$ (D) and MENA project

\begin{abstract}
Background: Olfaction is an important sense influencing food preferences, appetite, and eating behaviors. This hypothesis-driven study aimed to assess associations between olfactory pathway gene methylation signatures, obesity features, and dietary intakes.

Methods: A nutriepigenomic analysis was conducted in 474 adults from the Methyl Epigenome Network Association (MENA) project. Anthropometric measurements, clinical data, and serum metabolic profiles of the study population were obtained from structured databases of the MENA cohorts. Habitual dietary intake was assessed using a validated semiquantitative food frequency questionnaire. DNA methylation was measured in circulating white blood cells by microarray (Infinium Human Methylation $450 \mathrm{~K}$ BeadChips). FDR values $(p<0.0001)$ were used to select those CpGs that showed the best correlation with body mass index (BMI) and waist circumference (WC). Pathway analyses involving the characterization of genes involved in the olfactory transduction system were performed using KEGG and pathDIP reference databases.

Results: Overall, 15 CpG sites at olfactory pathway genes were associated with BMI $(p<0.0001)$ and WC $(p<0.0001)$ after adjustments for potential confounding factors. Together, methylation levels at the $15 \mathrm{CpG}$ sites accounted for 22\% and $20 \%$ of the variability in BMl and WC $\left(r^{2}=0.219, p<0.001\right.$, and $r^{2}=0.204, p<0.001$, respectively). These genes encompassed olfactory receptors (OR4D2, OR51A7, OR2T34, and OR2Y1) and several downstream signaling molecules (SLC8A1, ANO2, PDE2A, CALML3, GNG7, CALML6, PRKG1, and CAMK2D), which significantly regulated odor detection and signal transduction processes within the complete olfactory cascade, as revealed by pathway enrichment analyses $\left(p=1.94 \times 10^{-10}\right)$. Moreover, OR4D2 and OR2Y1 gene methylation patterns strongly correlated with daily intakes of total energy $(p<0.0001)$, carbohydrates $(p<0.0001)$, protein $(p<0.0001)$, and fat $(p<0.0001)$.

Conclusions: The results of this study suggest novel relationships between olfactory pathway gene methylation signatures, obesity indices, and dietary intakes.
\end{abstract}

Keywords: Olfactory system, Smell, Epigenetics, OR2Y1, OR4D2, Diet

\footnotetext{
* Correspondence: jalfmtz@unav.es

†Omar Ramos-Lopez and Jose I. Riezu-Boj contributed equally to this work.

${ }^{1}$ Department of Nutrition, Food Science and Physiology, and Center for

Nutrition Research, University of Navarra, 1 Irunlarrea Street, 31008 Pamplona,

Spain

${ }^{3}$ Navarra Institute for Health Research (IdiSNA), Pamplona, Spain

Full list of author information is available at the end of the article
}

(c) The Author(s). 2019 Open Access This article is distributed under the terms of the Creative Commons Attribution 4.0 International License (http://creativecommons.org/licenses/by/4.0/), which permits unrestricted use, distribution, and reproduction in any medium, provided you give appropriate credit to the original author(s) and the source, provide a link to the Creative Commons license, and indicate if changes were made. The Creative Commons Public Domain Dedication waiver (http://creativecommons.org/publicdomain/zero/1.0/) applies to the data made available in this article, unless otherwise stated. 


\section{Background}

Obesity epidemic represents one of the most important health challenges worldwide [1]. It has been estimated that about 1.9 billion adults present overweight or obesity based on body mass index (BMI), with an overall prevalence of $39 \%$ [2]. Epidemiological studies have identified high BMI as a risk factor for an expanding set of chronic diseases including cardiovascular disease, diabetes mellitus, non-alcoholic fatty liver disease, and many types of cancer, with relevant negative economic and social impacts [3]. At a global level, excessive weight $(\mathrm{BMI} \geq 25)$ accounted for 4 million deaths $(7.2 \%$ of all-cause deaths) and 120 million deaths and disabilityadjusted life years (4.9\% of all-cause DALYs) among adults in 2015 [4].

In general, the overconsumption of energy-dense foods, coupled with the adoption of a sedentary lifestyle, is the main environmental factors contributing to the development of obesity and associated clinical manifestations [5]. Moreover, genetic and epigenetic signatures play a role in determining individual susceptibility to fat accumulation $[6,7]$. In the past, and until recently, research on obesity has focused on characterizing the biological factors that predispose people to excessive food intake and associated weight gain [8]. In this context, it has been reported that sensorial modalities, including taste and olfaction [9], may influence food preferences and eating behaviors.

In particular, olfactory ability is related to perceived food palatability [10] and may be modulated by hunger/ satiety states $[11,12]$. Also, exposure to food odors increases appetite for products with similar characteristics in terms of taste and energy density [13]. Indeed, a link between dietary intake and olfactory sensitivity to fat was found [14], although another study did not find changes in energy intake or food preferences in response to odors exposure in women [15]. In addition, fluctuations in the internal levels of carbohydrates, amino acids, and fats could modulate olfactory sensitivity to adjust feeding behaviors in order to maintain nutrient homeostasis [16].

Odor perception during eating depends on the interaction between olfactory and gustatory systems [17]. Besides physiological issues (i.e., age, circadian rhythmicity, endocrine secretions), sensory variability can be also driven by genetic and epigenetic marks, which in turn can impact food consumption and subsequent health outcomes [18]. Associations between taste receptors polymorphisms, dietary intakes, lipid disorders, and liver disease in Mexican subjects were reported [19-22]. Likewise, sequence variants in olfactory receptor genes appeared to contribute to the predisposition to extreme obesity [23, 24] and influenced eating behaviors and adiposity levels [25]. Additionally, DNA methylation patterns at sweet taste pathway genes were associated with BMI and carbohydrate intake in an adult population [26]. Together, these findings suggest the involvement of sensory factors, including olfaction, in appetite regulation and obesity predisposition, where epigenetics may play a crucial role. This hypothesis-driven study aimed to assess associations between olfactory pathway gene methylation signatures, obesity features, and dietary intakes.

\section{Materials and methods \\ Subjects}

A nutriepigenomic analysis was conducted in an adult population from the Methyl Epigenome Network Association (MENA) project $(n=474)$, which is constituted by previous clinical trials [27-34]. The study protocol, data confidentiality, and research procedures were in accordance with the ethical principles on human experimentation stipulated in the 2013 Declaration of Helsinki by the World Medical Association [35].

\section{Study variables}

Anthropometric measurements, clinical data, and serum metabolic profiles of the study population were obtained from structured databases of the MENA cohorts. These variables included weight, height, waist circumference (WC), systolic blood pressure (SBP), diastolic blood pressure (DBP), glucose, insulin, total cholesterol, high-density lipoprotein cholesterol (HDL-c), lowdensity lipoprotein cholesterol (LDL-C), and triglycerides. BMI was calculated as the ratio between weight $(\mathrm{kg})$ and height $\left(\mathrm{m}^{2}\right)$. Insulin resistance was estimated by the homeostatic model assessment-insulin resistance (HOMA-IR) index using the following formula: HOMA-IR = fasting insulin $(\mathrm{mU} / \mathrm{L}) \quad \mathrm{X}$ plasma glucose $(\mathrm{mmol} / \mathrm{L}) / 22.5$. Triglyceride-glucose (TyG) index was calculated as a predictor of diabetes, as described elsewhere [36].

\section{Dietary assessment}

Dietary data was available from 247 subjects of the PREDIMED, RESMENA, and OBEKIT cohorts, which presented similar characteristics regarding the whole sample. A validated semiquantitative food frequency questionnaire [37] was used to assess the habitual consumption of 137 food items during the previous year according to four frequency categories (daily, weekly, monthly, or never). The obtained food portions and serving sizes were further converted to daily energy (kcal) and macronutrient intakes (g) using the Spanish food composition tables [38]. 


\section{DNA methylation analyses}

Venous blood samples were drawn by venipuncture after a 12-h overnight fast. White blood cells (WBC) were separated from whole blood by centrifugation at 3500 $\mathrm{rpm}$, at $4^{\circ} \mathrm{C}$ for $15 \mathrm{~min}$, and immediately frozen at $-80^{\circ}$ $\mathrm{C}$ in buffy coat until assay, as described elsewhere [39]. Genomic DNA was isolated from WBC with the Master Pure kit (Epicentre Biotechnologies, Madison, WI, USA). Purified DNA was quantified by the PicoGreen ${ }^{\circ}$ dsDNA Quantitation Reagent (Invitrogen, Carlsbad, CA, USA). High-quality DNA samples were modified with sodium bisulfite by using the EZ-96 DNA Methylation kit (Zymo Research Corporation, Irvine, CA, USA) according to the manufacturer's protocol. Bisulfite-treated DNA samples were hybridized to Infinium Human Methylation $450 \mathrm{~K}$ BeadChips (Illumina, San Diego, CA, USA) and scanned using the Illumina HiScanSQ system. Image intensities were obtained with the GenomeStudio Methylation Software Module, v1.9 (Illumina, San Diego, CA, USA). DNA methylation data pre-processing has been recently described elsewhere [40]. Briefly, CpG methylation levels were expressed as $\beta$ values ranging from 0 (unmethylated) to 1 (methylated) [41], which were corrected for type I and type II bias applying the peakbased correction. Data were normalized in R using a categorical Subset Quantile Normalization method [42]. Probes containing single-nucleotide polymorphisms, hybridizing to multiple genomic locations, or associated with $\mathrm{X}$ and $\mathrm{Y}$ chromosomes were removed from the analysis. Furthermore, DNA methylation variation explained due to different cell subtypes was corrected following the Houseman procedure [43].

\section{Pathway analyses}

Pathway mapping of genes involved in olfactory transduction (map04740) was performed using the Kyoto Encyclopedia of Genes and Genomes (KEGG) reference database (http://www.genome.jp/kegg/pathway.html). Subsequently, pathway enrichment analyses (confidence level of 99\%) were further run in the Pathway Data Integration Portal (pathDIP) platform, University of Toronto, Canada (http://ophid.utoronto.ca/pathdip/).

\section{Statistical analyses}

Data normality was screened by the KolmogorovSmirnov test. Principal variables including BMI, WC, energy, and macronutrient intakes were normally distributed $(p>0.05)$. Continuous variables were expressed as means \pm standard deviations, while categorical variables were presented as number of cases and percentages. Statistical analyses were performed in the IBM SPSS software, version 20 (IBM Inc., Armonk, NY, USA). A linear regression model (for BMI outcome) was computed in the LIMMA package for R software, which was adjusted by age, sex, study cohorts, and DNA methylation chips. Also, the Benjamini-Hochberg correction for multiple comparisons was applied. Statistically significant thresholds were based on false discovery rate $(\mathrm{FDR})$ cut-offs $(p<0.05)$ and B-statistic values $(>0)$ for BMI-related analysis. Afterwards, stricter FDR $(p<0.0001)$ were used to select those CpGs that showed the best correlation with BMI. Linear regression analyses adjusted by age and sex were further performed to evaluate correlations of methylation values at olfactory transducing genes with anthropometric (BMI, WC), metabolic (glucose, insulin, lipid profile, HOMA-IR, TyG index), and dietary measurements (total energy and macronutrient intakes). Figure plots showing significant correlations were created in the GraphPad Prism ${ }^{\circ}$ program, version 6.0C (La Jolla, CA, USA).

\section{Results}

Demographic, anthropometric, and metabolic characteristics of the whole study population are reported (Table 1 ). Thirty-six percent of subjects were men $(n=171)$. Eighty-two percent of the study population presented

Table 1 Demographic, anthropometric, and metabolic characteristics as well as dietary intake of the whole study population $(n=474)$

\begin{tabular}{|c|c|}
\hline Variable & Average values \\
\hline Age (years) & $47.2 \pm 14.1$ \\
\hline Men/women & $171 / 303$ \\
\hline \multicolumn{2}{|l|}{ Anthropometric and clinical data } \\
\hline Weight (kg) & $81.6 \pm 19.1$ \\
\hline $\mathrm{BMI}\left(\mathrm{kg} / \mathrm{m}^{2}\right)$ & $30.1 \pm 5.6$ \\
\hline WC $(\mathrm{cm})$ & $95.7 \pm 16.1$ \\
\hline MAP $(\mathrm{mmHg})$ & $100.4 \pm 16.2$ \\
\hline \multicolumn{2}{|l|}{ Metabolic profile } \\
\hline Glucose (mmol/L) & $5.7 \pm 1.7$ \\
\hline Insulin (pmol/L) & $66.7 \pm 48.6$ \\
\hline HOMA-IR index & $2.44 \pm 2.28$ \\
\hline Total cholesterol (mmol/L) & $5.3 \pm 1.0$ \\
\hline Triglycerides (mmol/L) & $1.4 \pm 0.8$ \\
\hline TyG index & $4.61 \pm 0.32$ \\
\hline \multicolumn{2}{|l|}{ Dietary intake } \\
\hline Energy (Kcal/day) & $2576 \pm 759$ \\
\hline Carbohydrates (g/day) & $260.9 \pm 96.8$ \\
\hline Protein (g/day) & $103.8 \pm 28.3$ \\
\hline Fat (g/day) & $115.3 \pm 36.4$ \\
\hline
\end{tabular}

Continuous variables are represented as means \pm standard deviations. Men and women are number of cases. BMI body mass index, WC waist circumference, MAP mean arterial pressure, HOMA-IR index homeostatic model assessment-insulin resistance index, TyG index triglyceride-glucose index. Dietary intake was available from 247 subjects 
excessive body weight $(n=390)$ according to the BMI classification of the World Health Organization $\left(B M I \geq 25 \mathrm{~kg} / \mathrm{m}^{2}\right)$. Regarding the reference values, the metabolic profile of the whole population was characterized by increased blood levels of glucose and total cholesterol.

The first screening revealed that $61 \mathrm{CpG}$ sites at genes participating in the olfactory transduction pathway correlated with the BMI $(p<0.05)$. Out of these, $35 \mathrm{CpGs}$ showed best correlations with BMI based on stricter FDR values $(p<0.0001)$. After performing linear regression tests adjusted by sex and age, $15 \mathrm{CpG}$ sites still remained statistically significant. These CpG sites comprised cg19302979 (SLC8A1), cg02874396 (OR4D2), cg10610428 (ANO2), cg12498094 (SLC8A1), cg07736155 (PDE2A), cg17283169 (CALML3), cg02849894 (GNG7), cg15102821 (CALML6), cg16401207 (PRKG1), cg00467296 (OR51A7), cg24609819 (PRKG1), cg13801347 (CAMK2D), cg1581
9352 (CALML6), cg13441213 (OR2T34), and cg18482656 (OR2Y1).

Interestingly, most of the BMI-associated CpGs were mapped to coding regions $(n=7)$ or terminal sequences $(n=2)$, and only six were located on gene promoters (Table 2). Together, methylation levels at these 15 CpG sites accounted for $22 \%$ of the variability in BMI $\left(r^{2}=0.219, p<0.001\right)$. Illustrative correlations of each CpG site are reported (Fig. 1). Moreover, methylation signatures at the aforementioned $15 \mathrm{CpGs}$ also correlated with WC values in a similar way (Fig. 2), explaining about $20 \%$ of variation in $\mathrm{WC}\left(r^{2}=0.204\right.$, $p<0.001)$. No statistically significant relationships between methylation status at olfactory transducing genes with blood levels of metabolic markers and blood pressure measurements were found.

Pathway mapping of the BMI-associated genes within the olfactory transduction cascade is shown (Fig. 3).

Table 2 Genomic and statistical data of CpG sites at olfactory pathway genes putatively associated with BMI

\begin{tabular}{|c|c|c|c|c|c|c|c|c|c|}
\hline$\overline{C p G \_I D^{1}}$ & Illumina_ID & Gene name & $\begin{array}{l}\text { Gene } \\
\text { symbol }\end{array}$ & $\begin{array}{l}\mathrm{CHR} \\
\text { position }^{2}\end{array}$ & $\begin{array}{l}\text { Genomic } \\
\text { region }\end{array}$ & $p$ value & FDR & B & $r^{2}$ \\
\hline 1 & cg19302979 & Solute carrier family 8 member $\mathrm{A} 1$ & SLCBA1 & 2: 40436843 & Body & $\begin{array}{l}4.0 \times \\
10^{-12}\end{array}$ & $3.2 \times 10^{-09}$ & 15.80 & 0.12 \\
\hline 2 & cg02874396 & $\begin{array}{l}\text { Olfactory receptor family } 4 \text { subfamily } D \\
\text { member } 2\end{array}$ & OR4D2 & 17: 56245848 & TSS1500 & $\begin{array}{l}1.3 \times \\
10^{-10}\end{array}$ & $4.4 \times 10^{-08}$ & 12.42 & 0.06 \\
\hline 3 & $\operatorname{cg} 10610428$ & Anoctamin 2 & ANO2 & 12: 5884295 & Body & $\begin{array}{l}1.5 \times \\
10^{-09}\end{array}$ & $2.7 \times 10^{-07}$ & 10.01 & 0.07 \\
\hline 4 & cg12498094 & Solute carrier family 8 member $\mathrm{A} 1$ & $S L C 8 A 1$ & 2: 40356782 & Body & $\begin{array}{l}1.4 \times \\
10^{-08}\end{array}$ & $\begin{array}{l}1.4 \times 10^{-} \\
06\end{array}$ & 7.81 & 0.05 \\
\hline 5 & cg07736155 & Phosphodiesterase $2 \mathrm{~A}$ & PDE2A & 11: 72354100 & TSS1500 & $\begin{array}{l}1.7 \times \\
10^{-08}\end{array}$ & $\begin{array}{l}1.6 \times 10^{-} \\
06\end{array}$ & 7.65 & 0.07 \\
\hline 6 & $\operatorname{cg} 17283169$ & Calmodulin-like 3 & CALML3 & 10: 5567524 & 3'UTR & $\begin{array}{l}2.1 \times \\
10^{-08}\end{array}$ & $\underbrace{2.0 \times 10^{-}}_{06}$ & 7.42 & 0.08 \\
\hline 7 & cg02849894 & G protein subunit gamma 7 & GNG7 & 19: 2608971 & $5^{\prime} U T R$ & $\begin{array}{l}4.5 \times \\
10^{-08}\end{array}$ & $3.4 \times 10^{-06}$ & 6.68 & 0.06 \\
\hline 8 & cg15102821 & Calmodulin-like 6 & CALML6 & 1: 1844801 & TSS1500 & $\begin{array}{l}1.4 \times \\
10^{-07}\end{array}$ & $7_{06}^{7.6 \times 10^{-}}$ & 5.61 & 0.05 \\
\hline 9 & $\operatorname{cg} 16401207$ & Protein kinase, cGMP-dependent, type I & PRKG1 & 10: 53182118 & Body & $\begin{array}{l}1.5 \times \\
10^{-07}\end{array}$ & $8.0 \times 10^{-06}$ & 5.54 & 0.05 \\
\hline 10 & cg00467296 & $\begin{array}{l}\text { Olfactory receptor family } 51 \text { subfamily A } \\
\text { member } 7\end{array}$ & OR51A7 & 11: 4928760 & 1stExon & $\begin{array}{l}1.9 \times \\
10^{-07}\end{array}$ & $9.7 \times 10^{-06}$ & 5.28 & 0.04 \\
\hline 11 & cg24609819 & Protein kinase, cGMP-dependent, type I & PRKG1 & 10: 52840377 & Body & $\begin{array}{l}3.8 \times \\
10^{-07}\end{array}$ & $1.6 \times 10^{-05}$ & 4.62 & 0.05 \\
\hline 12 & cg13801347 & $\begin{array}{l}\text { Calcium/calmodulin dependent protein } \\
\text { kinase II delta }\end{array}$ & CAMK2D & 4: 114460056 & Body & $\begin{array}{l}1.7 \times \\
10^{-06}\end{array}$ & $4.7 \times 10^{-05}$ & 3.14 & 0.05 \\
\hline 13 & cg15819352 & Calmodulin-like 6 & CALML6 & 1: 1845940 & TSS1500 & $\begin{array}{l}2.1 \times \\
10^{-06}\end{array}$ & $5.4 \times 10^{-05}$ & 2.96 & 0.05 \\
\hline 14 & cg13441213 & $\begin{array}{l}\text { Olfactory receptor family } 2 \text { subfamily } T \\
\text { member } 34\end{array}$ & OR2T34 & 1: 248738754 & TSS1500 & $\begin{array}{l}3.0 \times \\
10^{-06}\end{array}$ & $6.9 \times 10^{-05}$ & 2.62 & 0.05 \\
\hline 15 & cg18482656 & $\begin{array}{l}\text { Olfactory receptor family } 2 \text { subfamily } Y \\
\text { member } 1\end{array}$ & OR2Y1 & 5: 180167965 & TSS1500 & $\begin{array}{l}3.6 \times \\
10^{-06}\end{array}$ & $7.9 \mathrm{E}^{-05}$ & 2.45 & 0.05 \\
\hline
\end{tabular}

Data are sorted by FDR values

$B M I$ body mass index, CHR chromosome, FDR false discovery rate, B LIMMA B-statistic from LIMMA

${ }^{1}$ Studied $\mathrm{CpG}$ identifier

${ }^{2} \mathrm{CpG}$ locations were mapped using GRCh37 version of the genome from Ensembl platform 


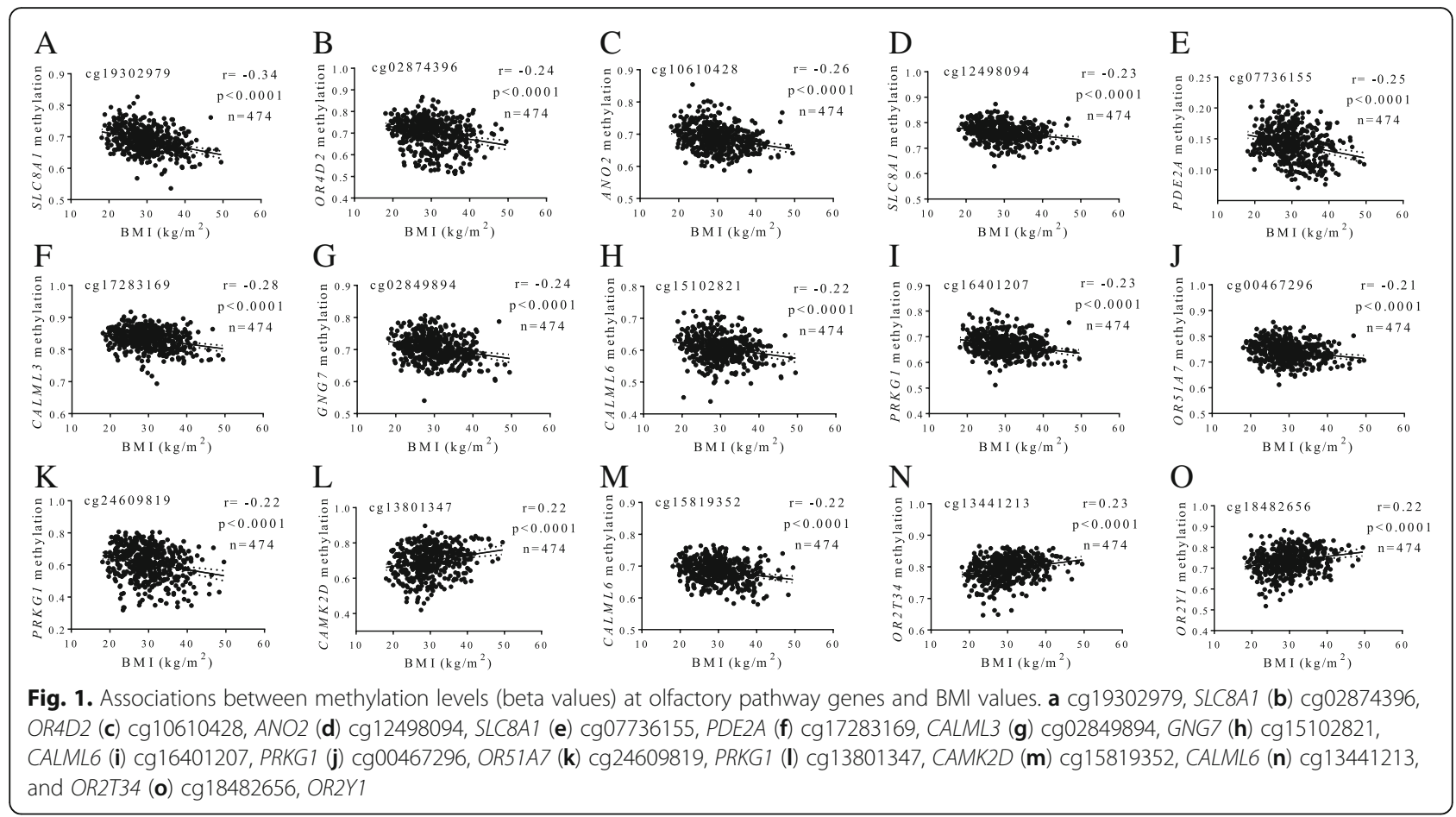

Notably, pathway enrichment analysis revealed a significant contribution $\left(p=1.94 \times 10^{-10}\right)$ of these genes to the regulation of the olfactory transduction network, which were involved in odor detection and signal processing in the nervous system (Fig. 3). These genes included the olfactory receptors OR4D2, OR51A7, OR2T34, and OR2Y1 and several downstream effectors, such as SLC8A1, ANO2, PDE2A, CALML3, GNG7, CALML6, PRKG1, and $C A M K 2 D$.

Furthermore, potential associations between olfactory receptor gene methylation status and dietary intakes were screened in a subsample of the MENA cohort

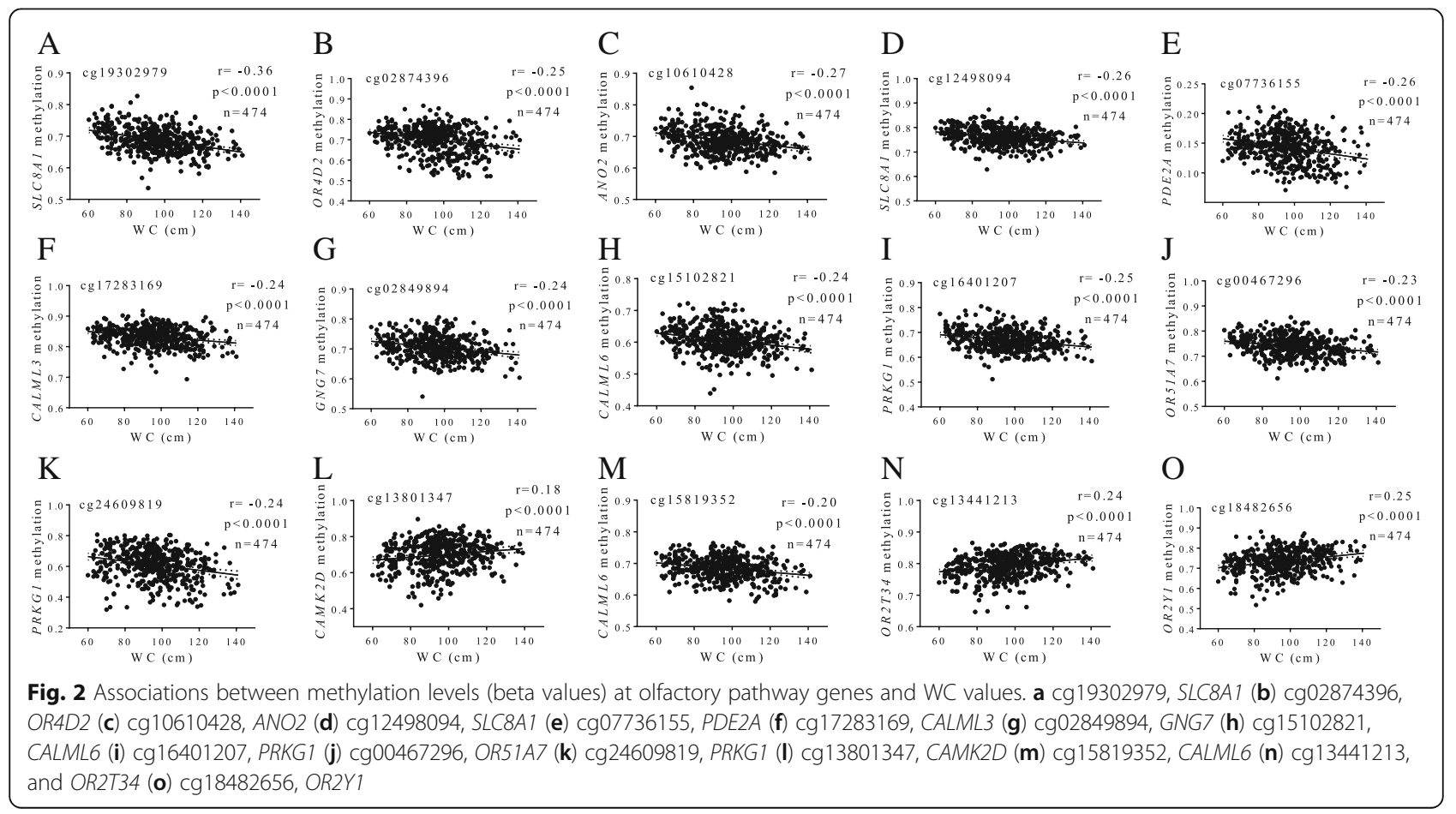


OLFACTORY TRANSDUCTION
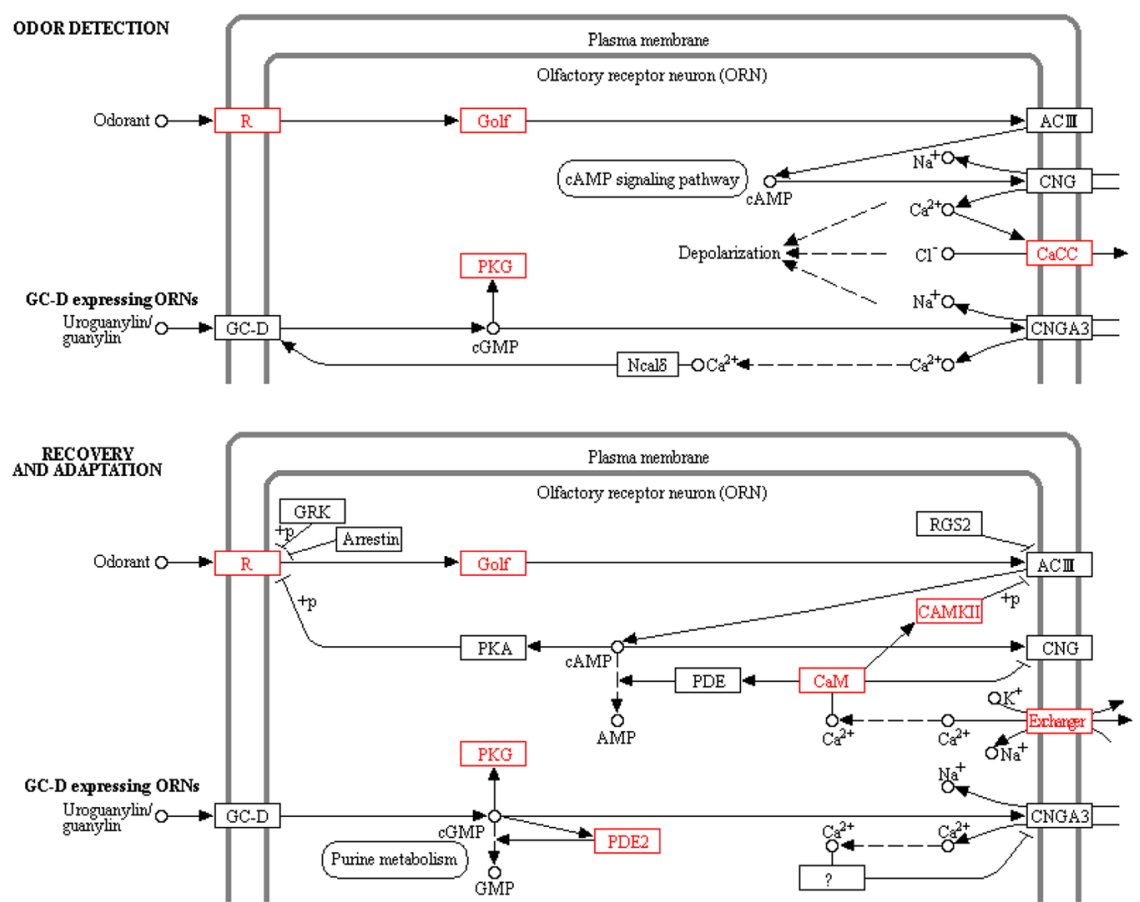

04740 1291915
(c) Kanehisa Laboratonies

Fig. 3 Pathway mapping of BMl-associated genes within the olfactory transduction network (red boxes). The following genes were computed: SLC8A1, OR4D2, ANO2, PDE2A, CALML3, GNG7, PRKG1, OR51A7, CAMK2D, CALML6, OR2T34, and OR2Y1. Figure taken from KEGG reference database (map04740). Pathway enrichment analyses, based on pathDIP $\left(p=1.94 \times 10^{-10}\right)$

(Fig. 4). Notably, methylation at cg02874396 (OR4D2) and cg18482656 (OR2Y1) strongly correlated with daily intakes of total energy $(p<0.0001)$, carbohydrates $(p<0.0001)$, protein $(p<0.0001)$, and fat $(p<0.0001)$.

\section{Discussion}

Olfaction is considered an important sensorial factor influencing feeding behaviors through modulating food palatability and appetite $[10,13]$. Thus, olfactory disruptions at the phenotypic and molecular levels may affect food intake and, consequently, individual predisposition to weight gain and obesity [9]. The current research shows, apparently for the first time, associations between different methylation patterns at olfactory pathway genes and adiposity indicators (BMI and waist circumference), which were independent of age and sex. These genes encompassed olfactory receptors (OR4D2, OR51A7, OR2T34, OR2Y1) and downstream signaling molecules (SLC8A1, ANO2, PDE2A, CALML3, GNG7, CALML6, PRKG1, CAMK2D), which significantly regulated odor detection and signal transduction within the complete olfactory cascade, as revealed by pathway analyses. Moreover, OR4D2 and OR2Y1 gene methylation patterns strongly correlated with daily energy and macronutrient intakes. The fact that methylation levels at $13 \mathrm{CpG}$ sites negatively correlated with BMI, and only $3 \mathrm{CpG}$ sites inversely positively associated with BMI, apparently reveal gene-specific profiling of DNA methylation regarding olfactory methylation status and obesity. These findings may contribute to elucidating novel relationships between olfactory system epigenetics, food consumption, and body weight homeostasis.

Odorant signal transduction is initiated when volatile odorants (including those emanating from food) interact with specific olfactory receptors in the nasal olfactory epithelium, leading to the initial perception of smell in the brain [44]. It has been reported that olfactory receptors are also expressed in nonchemosensory tissues, where they perform multiple physiological and metabolic functions [45]. The results found in this research are consistent with the role of olfactory perception in regulating food intake and energetic balance, as reported elsewhere [13, 14, 16]. Interestingly, genome-wide association analyses detected copy number variations in olfactory receptor genes that were associated with early-onset extreme 

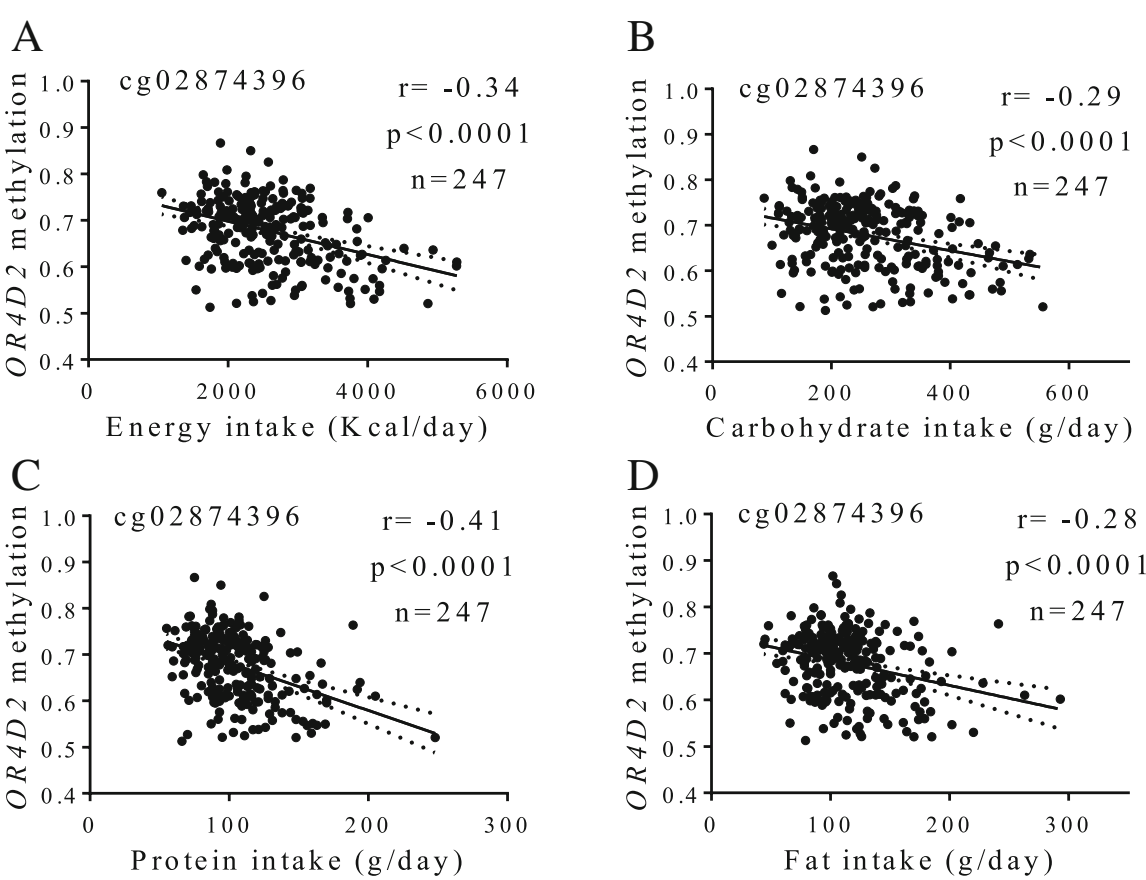

$\mathrm{D}$

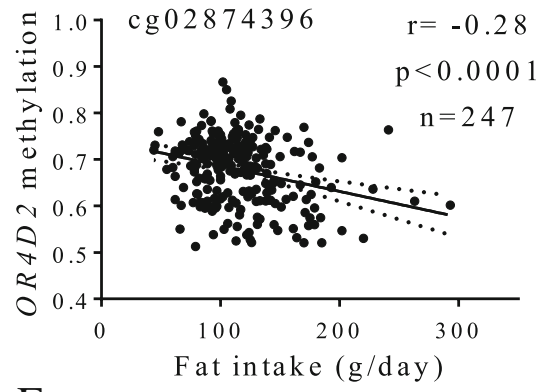

\section{E}

$\mathrm{F}$
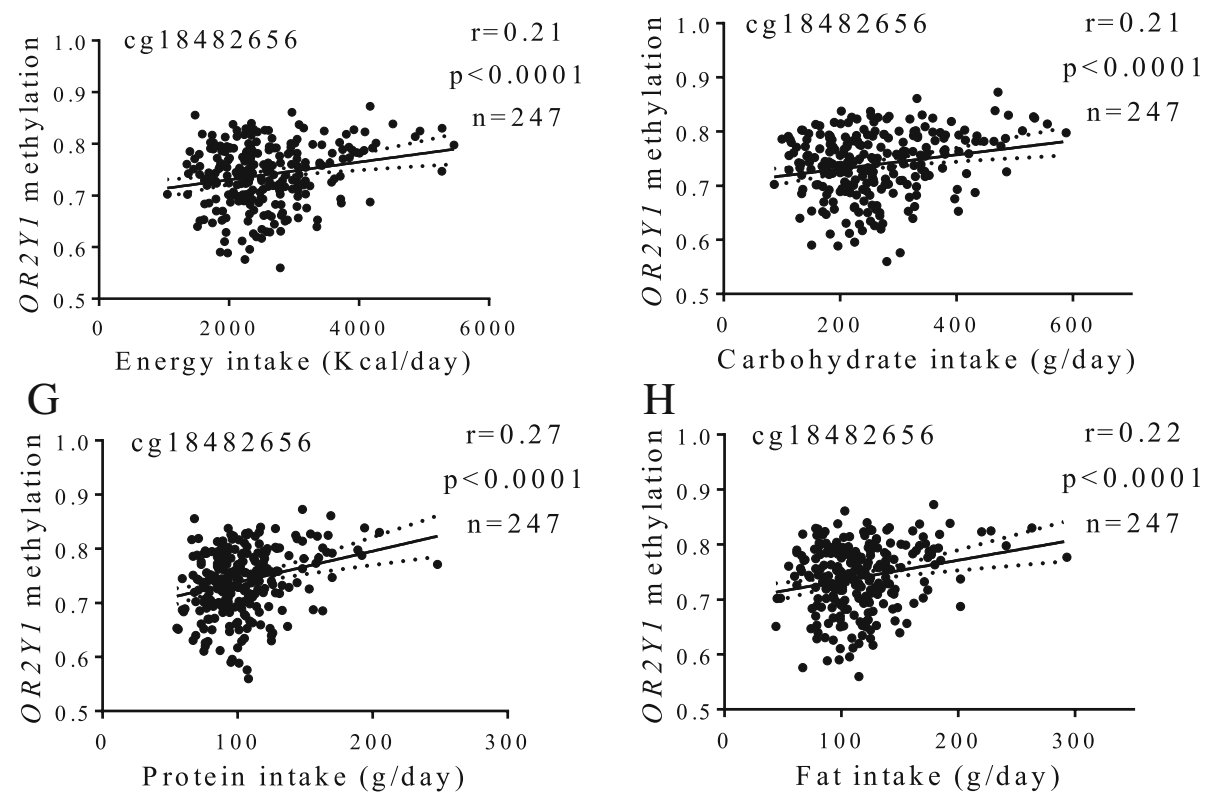

Fig. 4 Associations between methylation levels (beta values) at olfactory receptors and dietary intakes. a-d cg02874396, OR4D2 (e-h) cg18482656, OR2Y1

obesity in humans [23]. Also, predicted damaging missense variants in olfactory receptor and protocadherin beta cluster genes were co-localized in subjects with extreme obesity [24]. Similarly, olfactory receptor gene polymorphisms showed evidence of an association with adiposity levels and some eating behaviors, including cognitive dietary restraint, susceptibility to hunger, and eating disinhibition [25].
Regarding odor-evoked transducers, PRKG1, a cGMPdependent protein kinase, involved in foraging behavior, food acquisition, and energy balance, was located within a variably methylated region associated with BMI in a human cohort [46]. Until now, the specific roles of ANO2, CAMK2D, SLC8A1, PDE2A, CALML3, GNG7, and CALML6 genes in olfactory-related dietary patterns and obesity in humans have not been apparently 
explored; therefore, further investigation in these research areas is warranted.

Potential relationships between eating patterns, olfactory function, and obesity have also been phenotypically studied. In this context, consumers of a Western-style diet (rich in saturated fat and added sugar) presented poorer odor identification ability, worse fat discrimination, and hedonic differences in taste and flavor perception relative to people who consumed a healthier diet [47]. Of note, an increasing BMI has been associated with a decrease in olfactory sensitivity [48]. High BMI was also related to subjective olfactory dysfunction in obese patients [49]. In addition, an impaired olfactory capacity has been reported in obese subjects compared to normal-weight controls [50]. Furthermore, an increase in visceral fat content was associated with a decrease in olfactory function [51].

To the best of our knowledge, this is a pioneer study exploring the role of epigenetics of olfaction in obesity. The strengths of this investigation include the screening of the whole olfactory transduction pathway and the relative large number of DNA samples analyzed. Moreover, methylation-related statistical analyses were adjusted for potential confounding factors such as sex, age, study cohorts, methylation chips, and cell composition variability as well as with corrections for multiple comparisons within the experiments performed in this study. Instead, the limitations of this study encompass those inherent to retrospective association studies including the inability to explain cause-effect relationships, the scientific caution concerning the reproducibility of the findings in other administrative settings having their own peculiar biases, and the difficulties in distinguishing between factors related to increased or decreased risk of developing the disease and those associated with the course of the illness [52]. Other drawbacks of this study comprise the exclusion of expression assays (RNA samples were not available) and the lack of tests evaluating olfactory function. Also, given the number of subjects analyzed and the type of study (association) type I and type II bias cannot be completely excluded despite the statistical settings. Likewise, some methylation relevant data related to obesity could have not been taken into account due to the use of rigorous FDR thresholds in the outcome-related analyses.

Another issue of this study could be the fact that DNA methylation levels were measured in circulating white blood cells instead of olfactory tissues. Interestingly, the expression of some olfactory receptors has been detected in different blood cells, including OR51A7 in leukocytes [53]. Also, our results are in accordance with a previous investigation showing associations between methylation signatures at sweet taste transducing genes, obesity, and carbohydrate intake [26]. Additionally, some studies support that methylation marks in blood cells can mirror those found in other samples, including oral mucosa [54] and subcutaneous adipose tissue [55], suggesting the possible use of the methylome in leukocytes for disease-risk prediction and therapeutic purposes.

In recent years, the implication of different epigenetic processes in the development of obesity is being extensively investigated [56]. Especially, altered DNA methylation patterns can trigger changes in gene expression associated with deregulations of energy homeostasis and weight gain predisposition [7]. In this manner, genes integrating the olfactory pathway are susceptible to covalent epigenetic modifications that might lead to odor perception dysfunction. Establishing an epigenetic basis for olfactory function may help to understand, at least in part, relationships between olfaction capacity, food consumption, and body weight regulation. In turn, this knowledge may contribute to identify epigenetic biomarkers to predict the risk of developing excessive adiposity and associated comorbidities, as well as implement epigenome-based dietary strategies for prevention, prognosis, and treatment of obesity within the era of precision nutrition [57].

\section{Conclusions}

The results of this investigation suggest novel relationships between olfactory pathway gene methylation signatures, obesity indices, and dietary intakes.

\section{Acknowledgements}

Authors thank all the participants of this study and the personnel of the primary health centers. Technical and laboratory support from Asuncion Redin, Laura Olazaran, losune Zubieta, Maria Hernandez, Salome Perez, Blanca Martinez de Morentin, Ana Lorente, Veronica Ciaurriz, and Maria Zabala is gratefully acknowledged. The MENA Project is constituted by the cohorts PREDIMED, OBEPALIP, GEDYMET, DiOGenes, RESMENA, NUGENOB, Food4Me, and ICTUS, where each of the following researchers in alphabetical order are involved: Alonso A, Arancibia C, Arós F, Astrup A, Babio N, Blázquez V, Bondia-Pons I, Brennan L, Buil-Cosiales P, Campión J, Cataldo LR, Celis-Morales C, Corella D, Covas MI, Dalskov S, Daniel H, De Arce A, de la Iglesia R, Estruch R, Fernández-Crehuet J, Fiol M, Fitó M, Flores M, Forga L, Galgani J, Gibney ER, Gibney MJ, Gómez-Úriz AM, González-Muniesa P, Goyenechea E, Guy-Grand B, Handjieva-Darlenska T, Holst C, Huerta AE, Jebb S, Kafatos A, Kunesová M, Lamuela-Raventós RM, Langin D, Lapetra J, Larsen TM, López De Munain A, López-Legarrea P, Lovegrove JA, Macdonald I, Manios Y, Martínez-Zabaleta MT, Mathers JC, Morales M, Muñoz MA, Olmos P, Pedersen O, Petersen M, Pfeiffer A, Pintó X, Pollak F, PREDIMED Investigators, Prieto-Hontoria PL, Ros E, Rössner S, Ruiz-Gutierrez V, Salas-Salvadó J, Saris WH, Serra-Majem L, Sørensen TI, Sorli JV, Stich V, Taylor MA, Toledo E, Toubro S, Traczyk I, Valderas JP, van Baak M, Vega J, Verdich C, Walsh M, and Yévenes I.

Other members of the MENA project in alphabetical order are Abete I, Crujeiras AB, Cuervo M, Goni L, Marti A, Martinez-Gonzalez MA, MorenoAliaga MJ, Navas-Carretero S, and San-Cristobal R.

The final reading completed by the native English speaker (Nora Goodwin from Technological University Dublin) is gratefully acknowledged.

\section{Funding}

This research was supported by grants from the Government of Navarra (PT024), CIBERobn (CB12/03/30002), MINECO (AGL2013-45554-R), and NUTRIGENIO (AGL2013-45554-R). O. R. L. was supported by a 2-year postdoctoral grant from National Council of Science and Technology, Mexico 
(CONACyT, Num. CVU. 444175), in collaboration with the PhD Program in Molecular Biology in Medicine, University of Guadalajara, Mexico (CONACyT, PNPC 000091), and the University of Navarra, Spain (LE/97).

\section{Availability of data and materials}

The datasets used and/or analyzed during the current study are available from the corresponding author on reasonable request.

\section{Authors' contributions}

JAM conceived the study, revised data, wrote, and critically revised the content of this article. ORL and JIR performed the statistical analysis and prepared the first draft of the manuscript. FIM, JLS, and MAZ wrote and critically revised the content of this article. All authors critically reviewed all drafts and approved the final manuscript.

\section{Ethics approval and consent to participate}

All procedures performed in this study were in accordance with the ethical standards of the Research Committee of the University of Navarra and with the 1964 Helsinki Declaration and its 2013 amendments. Informed consent was obtained from all individual participants before included in the study.

\section{Consent for publication}

Not applicable.

\section{Competing interests}

The authors declare that they have no competing interests.

\section{Publisher's Note}

Springer Nature remains neutral with regard to jurisdictional claims in published maps and institutional affiliations.

\section{Author details}

'Department of Nutrition, Food Science and Physiology, and Center for Nutrition Research, University of Navarra, 1 Irunlarrea Street, 31008 Pamplona, Spain. ${ }^{2}$ Medical and Psychology School, Autonomous University of Baja California, Tijuana, Baja California, Mexico. ${ }^{3}$ Navarra Institute for Health Research (IdiSNA), Pamplona, Spain. ${ }^{4}$ CIBERobn, Fisiopatología de la Obesidad y la Nutrición; Carlos III Health Institute, Madrid, Spain. ${ }^{5}$ Department of Nutrition, Diabetes and Metabolism, School of Medicine, Pontificia Universidad Católica de Chile, Santiago, Chile. ${ }^{6}$ Madrid Institute of Advanced Studies (IMDEA Food), Madrid, Spain.

\section{Received: 12 October 2018 Accepted: 9 April 2019}

\section{Published online: 25 April 2019}

\section{References}

1. Friedrich MJ. Global obesity epidemic worsening. JAMA. 2017;318:603.

2. World Health Organization: Obesity and overweight (2017). http://www. who.int/mediacentre/factsheets/fs311/en/. Accessed 03 Mar 2018.

3. Seidell JC, Halberstadt J. The global burden of obesity and the challenges of prevention. Ann Nutr Metab. 2015;66(Suppl 2):7-12.

4. GBD 2015 Obesity Collaborators. Health effects of overweight and obesity in 195 countries over 25 years. N Engl J Med. 2017;377:13-27.

5. Kang JX. Nutritional problems and solutions for the modern health epidemic. J Nutrigenet Nutrigenomics. 2014;7:188-90.

6. Goni L, Milagro Fl, Cuervo M, Martínez JA. Single-nucleotide polymorphisms and DNA methylation markers associated with central obesity and regulation of body weight. Nutr Rev. 2014;72:673-90.

7. Martínez JA, Milagro FI, Claycombe KJ, Schalinske KL. Epigenetics in adipose tissue, obesity, weight loss, and diabetes. Adv Nutr. 2014;5:71-81.

8. Apovian CM, Riffenburg KM. Perspectives on the global obesity epidemic. Curr Opin Endocrinol Diabetes Obes. 2017;24:307-9.

9. Rolls ET. Taste, olfactory, and food reward value processing in the brain. Prog Neurobiol. 2015;127-128:64-90.

10. Cameron JD, Goldfield GS, Doucet É. Fasting for $24 \mathrm{~h}$ improves nasal chemosensory performance and food palatability in a related manner. Appetite. 2012;58:978-81.

11. Hanci D, Altun H. Hunger state affects both olfactory abilities and gustatory sensitivity. Eur Arch Otorhinolaryngol. 2016;273:1637-41.
12. Sun $X$, Veldhuizen MG, Babbs AE, Sinha R, Small DM. Perceptual and brain response to odors is associated with body mass index and postprandial total ghrelin reactivity to a meal. Chem Senses. 2016;41:233-48.

13. Zoon HF, de Graaf C, Boesveldt S. Food odours direct specific appetite. Foods. 2016. https://doi.org/10.3390/foods5010012.

14. Kindleysides S, Beck KL, Walsh DCl, Henderson L, Jayasinghe SN, Golding M, Breier $\mathrm{BH}$. Fat sensation: fatty acid taste and olfaction sensitivity and the link with disinhibited eating behaviour. Nutrients. 2017. https://doi.org/10.3390/ nu9080879.

15. Zoon HF, He W, de Wijk RA, de Graaf C, Boesveldt S. Food preference and intake in response to ambient odours in overweight and normal-weight females. Physiol Behav. 2014;133:190-6.

16. Julliard AK, Al Koborssy D, Fadool DA, Palouzier-Paulignan B. Nutrient sensing: another chemosensitivity of the olfactory system. Front Physiol. 2017:8:468.

17. Green BG, Nachtigal D, Hammond S, Lim J. Enhancement of retronasal odors by taste. Chem Senses. 2012;37:77-86.

18. Loper HB, La Sala M, Dotson C, Steinle N. Taste perception, associated hormonal modulation, and nutrient intake. Nutr Rev. 2015;73:83-91.

19. Ramos-Lopez O, Roman S, Martinez-Lopez E, Gonzalez-Aldaco K, OjedaGranados C, Sepulveda-Villegas M, Panduro A. Association of a novel TAS2R38 haplotype with alcohol intake among Mexican-mestizo population. Ann Hepatol. 2015;14:729-34.

20. Ramos-Lopez O, Panduro A, Martinez-Lopez E, Fierro NA, Ojeda-Granados C, Sepulveda-Villegas M, Roman S. Genetic variant in the CD36 gene (rs1761667) is associated with higher fat intake and high serum cholesterol among the population of West Mexico. J Nutr Food Sci. 2015;5:353.

21. Ramos-Lopez O, Panduro A, Martinez-Lopez E, Roman S. Sweet taste receptor TAS1R2 polymorphism (Val191Val) is associated with a higher carbohydrate intake and hypertriglyceridemia among the population of West Mexico. Nutrients. 2016;8:101.

22. Ramos-Lopez O, Roman S, Martinez-Lopez E, Fierro NA, Gonzalez-Aldaco K, Jose-Abrego A, Panduro A. CD36 genetic variation, fat intake and liver fibrosis in chronic hepatitis C virus infection. World J Hepatol. 2016;8:1067-74.

23. Jarick I, Vogel Cl, Scherag S, Schäfer H, Hebebrand J, Hinney A, Scherag A. Novel common copy number variation for early onset extreme obesity on chromosome 11q11 identified by a genome-wide analysis. Hum Mol Genet. 2011;20:840-52

24. Mariman EC, Szklarczyk R, Bouwman FG, Aller EE, van Baak MA, Wang P. Olfactory receptor genes cooperate with protocadherin genes in human extreme obesity. Genes Nutr. 2015;10:465.

25. Choquette AC, Bouchard L, Drapeau V, Lemieux S, Tremblay A, Bouchard C, Vohl MC, Pérusse L. Association between olfactory receptor genes, eating behavior traits and adiposity: results from the Quebec Family Study. Physiol Behav. 2012;105:772-6.

26. Ramos-Lopez O, Arpón A, Riezu-Boj Jl, Milagro Fl, Mansego ML, Martinez JA, MENA project. DNA methylation patterns at sweet taste transducing genes are associated with BMI and carbohydrate intake in an adult population. Appetite. 2018;120:230-9.

27. Larsen TM, Dalskov S, van Baak M, Jebb S, Kafatos A, Pfeiffer A, Martinez JA, Handjieva-Darlenska T, Kunesová M, Holst C, Saris WH, Astrup A. The Diet, Obesity and Genes (Diogenes) Dietary Study in eight European countries - a comprehensive design for long-term intervention. Obes Rev. 2010;11:76-91.

28. Zulet MA, Bondia-Pons I, Abete I, de la Iglesia R, López-Legarrea P, Forga L, Navas-Carretero S, Martínez JA. The reduction of the metabolyc syndrome in Navarra-Spain (RESMENA-S) study: a multidisciplinary strategy based on chrononutrition and nutritional education, together with dietetic and psychological control. Nutr Hosp. 2011;26:16-26.

29. Petersen M, Taylor MA, Saris WH, Verdich C, Toubro S, Macdonald I, Rössner S, Stich V, Guy-Grand B, Langin D, Martinez JA, Pedersen O, Holst C, Sørensen TI, Astrup A. Randomized, multi-center trial of two hypo-energetic diets in obese subjects: high- versus low-fat content. Int J Obes. 2006;30: 552-60

30. San-Cristobal R, Navas-Carretero S, Celis-Morales C, Brennan L, Walsh M, Lovegrove JA, Daniel H, Saris WH, Traczyk I, Manios Y, Gibney ER, Gibney MJ, Mathers JC, Martinez JA. Analysis of dietary pattern impact on weight status for personalised nutrition through on-line advice: the Food4Me Spanish cohort. Nutrients. 2015:7:9523-37.

31. Martínez-González MÁ, Toledo E, Arós F, Fiol M, Corella D, Salas-Salvadó J, Ros E, Covas MI, Fernández-Crehuet J, Lapetra J, Muñoz MA, Fitó M, SerraMajem L, Pintó X, Lamuela-Raventós RM, Sorlí JV, Babio N, Buil-Cosiales P, 
Ruiz-Gutierrez V, Estruch R, Alonso A, PREDIMED Investigators. Extravirgin olive oil consumption reduces risk of atrial fibrillation: the PREDIMED (Prevención con Dieta Mediterránea) trial. Circulation. 2014;130:18-26.

32. Huerta AE, Navas-Carretero S, Prieto-Hontoria PL, Martínez JA, Moreno-Aliaga MJ. Effects of a-lipoic acid and eicosapentaenoic acid in overweight and obese women during weight loss. Obesity (Silver Spring). 2015;23:313-21.

33. Santos JL, Yévenes I, Cataldo LR, Morales M, Galgani J, Arancibia C, Vega J, Olmos P, Flores M, Valderas JP, Pollak F. Development and assessment of the disposition index based on the oral glucose tolerance test in subjects with different glycaemic status. J Physiol Biochem. 2016;72:121-31.

34. Abete I, Gómez-Úriz AM, Mansego ML, De Arce A, Goyenechea E, Blázquez V, Martínez-Zabaleta MT, González-Muniesa P, López De Munain A, Martínez JA, Campión J, Milagro Fl. Epigenetic changes in the methylation patterns of KCNQ1 and WT1 after a weight loss intervention program in obese stroke patients. Curr Neurovasc Res. 2015;12:321-33.

35. World Medical Association (WMA). World Medical Association Declaration of Helsinki: ethical principles for medical research involving human subjects. JAMA. 2013;310:2191-4.

36. Navarro-González D, Sánchez-lñigo L, Pastrana-Delgado J, FernándezMontero A, Martinez JA. Triglyceride-glucose index (TyG index) in comparison with fasting plasma glucose improved diabetes prediction in patients with normal fasting glucose: The Vascular-Metabolic CUN cohort. Prev Med. 2016;86:99-105.

37. de la Fuente-Arrillaga C, Ruiz Z, Bes-Rastrollo M, Sampson L, MartinezGonzalez M. Reproducibility of an FFQ validated in Spain. Public Health Nutr. 2010;13:1364-72.

38. Moreiras O, Carbajal A, Cabrera L, Cuadrado C. Tablas de composición de alimentos, guía de prácticas. 16th ed. Madrid: Pirámide; 2016.

39. Arpón A, Riezu-Boj Jl, Milagro Fl, Marti A, Razquin C, Martínez-González MA, Corella D, Estruch R, Casas R, Fitó M, Ros E, Salas-Salvadó J, Martínez JA. Adherence to Mediterranean diet is associated with methylation changes in inflammation-related genes in peripheral blood cells. J Physiol Biochem. 2016;73:445-55.

40. Mansego ML, Garcia-Lacarte M, Milagro FI, Marti A, Martinez JA, GENO members. DNA methylation of miRNA coding sequences putatively associated with childhood obesity. Pediatr Obes. 2017;12:19-27.

41. Du P, Kibbe WA, Lin SM. lumi: a pipeline for processing Illumina microarray. Bioinformatics. 2008;24:1547-8.

42. Touleimat N, Tost J. Complete pipeline for Infinium (') Human Methylation 450K BeadChip data processing using subset quantile normalization for accurate DNA methylation estimation. Epigenomics. 2012;4:325-41.

43. Houseman EA, Accomando WP, Koestler DC, Christensen BC, Marsit CJ, Nelson HH, Wiencke JK, Kelsey KT. DNA methylation arrays as surrogate measures of cell mixture distribution. BMC Bioinf. 2012;13:86.

44. Ihara S, Yoshikawa K, Touhara K. Chemosensory signals and their receptors in the olfactory neural system. Neuroscience. 2013;254:45-60.

45. Kang $\mathrm{N}$, Koo J. Olfactory receptors in non-chemosensory tissues. BMB Rep. 2012;45:612-22.

46. Feinberg AP, Irizarry RA, Fradin D, Aryee MJ, Murakami P, Aspelund T, Eiriksdottir G, Harris TB, Launer L, Gudnason V, Fallin MD. Personalized epigenomic signatures that are stable over time and covary with body mass index. Sci Transl Med. 2010;2:49ra67.

47. Stevenson RJ, Boakes RA, Oaten MJ, Yeomans MR, Mahmut M, Francis HM. Chemosensory abilities in consumers of a Western-style diet. Chem Senses. 2016:41:505-13.

48. Skrandies W, Zschieschang R. Olfactory and gustatory functions and its relation to body weight. Physiol Behav. 2015;142:1-4

49. Patel ZM, DelGaudio JM, Wise SK. Higher body mass index is associated with subjective olfactory dysfunction. Behav Neurol. 2015;2015:675635.

50. Pastor $A$, Fernández-Aranda F, Fitó $M$, Jiménez-Murcia $S$, Botella $C$, Fernández-Real JM, Frühbeck G, Tinahones FJ, Fagundo AB, Rodriguez J, Agüera Z, Langohr K, Casanueva FF, de la Torre R. A lower olfactory capacity is related to higher circulating concentrations of endocannabinoid 2arachidonoylglycerol and higher body mass index in women. PLoS One. 2016;11:e0148734.

51. Fernandez-Garcia JC, Alcaide J, Santiago-Fernandez C, Roca-Rodriguez MM, Aguera Z, Baños R, Botella C, de la Torre R, Fernandez-Real JM, Fruhbeck G, Gomez-Ambrosi J, Jimenez-Murcia S, Menchon JM, Casanueva FF, Fernandez-Aranda F, Tinahones FJ, Garrido-Sanchez L. An increase in visceral fat is associated with a decrease in the taste and olfactory capacity. PLoS One. 2017;12:e0171204.
52. Mantel N, Haenszel W. Statistical aspects of the analysis of data from retrospective studies of disease. J Natl Cancer Inst. 1959;22:719-48.

53. Malki A, Fiedler J, Fricke K, Ballweg I, Pfaffl MW, Krautwurst D. Class I odorant receptors, TAS1R and TAS2R taste receptors, are markers for subpopulations of circulating leukocytes. J Leukoc Biol. 2015;97:533-45.

54. San-Cristobal R, Navas-Carretero S, Milagro FI, Riezu-Boj Jl, Guruceaga E, CelisMorales C, Livingstone KM, Brennan L, Lovegrove JA, Daniel H, Saris WH, Traczyk I, Manios Y, Gibney ER, Gibney MJ, Mathers JC, Martinez JA. Gene methylation parallelisms between peripheral blood cells and oral mucosa samples in relation to overweight. J Physiol Biochem. 2016;73:465-74.

55. Crujeiras AB, Diaz-Lagares A, Sandoval J, Milagro Fl, Navas-Carretero S, Carreira MC, Gomez A, Hervas D, Monteiro MP, Casanueva FF, Esteller M, Martinez JA. DNA methylation map in circulating leukocytes mirrors subcutaneous adipose tissue methylation pattern: a genome-wide analysis from non-obese and obese patients. Sci Rep. 2017;7:41903.

56. Milagro Fl, Mansego ML, De Miguel C, Martínez JA. Dietary factors, epigenetic modifications and obesity outcomes: progresses and perspectives. Mol Asp Med. 2013;34:782-812.

57. Ramos-Lopez O, Milagro Fl, Allayee H, Chmurzynska A, Choi MS, Curi R, De Caterina R, Ferguson LR, Goni L, Kang JX, Kohlmeier M, Marti A, Moreno LA, Pérusse L, Prasad C, Qi L, Reifen R, Riezu-Boj Jl, San-Cristobal R, Santos JL, Martínez JA. Guide for current nutrigenetic, nutrigenomic, and nutriepigenetic approaches for precision nutrition involving the prevention and management of chronic diseases associated with obesity. J Nutrigenet Nutrigenomics. 2017;10:43-62.

\section{Ready to submit your research? Choose BMC and benefit from:}

- fast, convenient online submission

- thorough peer review by experienced researchers in your field

- rapid publication on acceptance

- support for research data, including large and complex data types

- gold Open Access which fosters wider collaboration and increased citations

- maximum visibility for your research: over $100 \mathrm{M}$ website views per year

At BMC, research is always in progress.

Learn more biomedcentral.com/submissions 